foidfrakturer med tanke på tilheling, sykmelding, gripestyrke, bevegelighet eller pasienttilfredshet (2). Senere studier har støttet dette (3). Operasjon tenderer til raskere gjenvinning av bevegelse og styrke enn gipsbehandling. Effekten er forbigående, og ingen forskjell lot seg påvise etter $1-10$ år $(2,3)$. Utenlandske studier vedrørende kostnadseffektivitet er ikke direkte overførbare til nordiske forhold. Sykmeldingsvarigheten er mest avhengig av sykepengeordningen. En svensk randomisert studie viste nylig lavere totale kostnader ved gipsbehandling enn ved kirurgi hos pasienter som ikke var kroppsarbeidere.

Ekspertstudier demonstrerer langt flere komplikasjoner ved operasjon, særlig skafotrapezial artrose og skrueproblemer $(2,3)$. Vi synes ikke skafoidkirurgi er enkelt, og økningen av henvisninger til regionsnivå tyder på at mange er enige. Os scaphoideum har leddfasetter over nesten hele overflaten. Det er lett å få skrueperforasjon, som kan ødelegge håndleddet. Inntil 1500 årlige skafoidosteosynteser ville føre til betydelige kompetansemessige og kapasitetsmessige problemer. Systematisert gipsbehandling av skaoidfrakturer er nesten komplikasjonsfri og gir høy grad av tilheling. I et årsmateriale fra Oslo skadelegevakt ble to av 154 skafoidfrakturer operert primært på grunn av dislokasjon. De resterende 152 ble gipsbehandlet. Kun tre utviklet pseudartrose, $98 \%$ tilhelet (4).

Vi anbefaler gipsbehandling av udislokerte eller minimalt dislokerte skafoidfrakturer. Kombinasjon med andre håndrotsskader, dislokasjon over $1 \mathrm{~mm}$, manglende behandling i fire uker eller ingen tegn til tilheling etter fire måneder gir operasjonsindikasjon. CT kan gi verdifull informasjon om tilhelingen. Ved særlig behov for rask mobilisering kan skrueosteosyntese ved udislokerte skafoidfrakturer forsvares, forutsatt grundig informasjon og aksept av den forøkede risikoen for komplikasjoner.

Derimot er vi helt enig med Hove (1) om at avdelinger som behandler slike frakturer, må ha rask tilgang til MR. Erfaringene fra Oslo skadelegevakt bekrefter at kun $15 \%$ av pasientene som gipsbehandles for klinisk mistenkt skafoidfraktur, har positivt primærrøntgenfunn. Ved negativt røntgenfunn viste MR $25 \%$ skafoidfraktur, $14 \%$ brudd i tilgrensende knokler, $22 \%$ skade på det subkondrale bein (bone bruise) og $38 \%$ ingen skjelettskade (4). I vårt noe haltende helsevesen bør hovedutfordringen være å sikre pasientene tidlig MR for å avdekke bruddene fremfor å være så opptatt av at flere skal opereres.

\section{Magne Røkkum}

Oslo universitetssykehus, Rikshospitalet

Knut Melhuus

Oslo skadelegevakt
Litteratur

. Hove LM. Håndrotsbrudd - på tide med ny praksis! Tidsskr Nor Legeforen 2009; 129: 176.

2. Yin Z-G, Zhang J-B, Kan S-L et al. Treatment of acute scaphoid fractures. Systematic review and metaanalysis. Clin Orthop Rel Res 2007; 460: 142-51.

3. Vinnars B, Pietreanu M, Bodestedt $\AA$ et al. Non operative compared with operative treatment of acute scaphoid fractures. A randomized clinical Joint Surg Am 2008: 90: 1176-85.

4. Glad TH, Melhuus K. Scafoidfrakturer ved Oslo skadelegevakt. Ortopedisk høstmøte, 2008. Oslo: Den norske legeforening. Norsk ortopedisk forening, 2008

\section{M. Hove svarer:}

Magne Røkkum \& Knut Melhuus viser bl.a. til «nyere studier» som er fra årene 1992-97 (1). I disse studiene undersøkte man imidlertid pasienter som hadde fått utført åpen kirurgi, og ikke perkutan operasjon med kanylert skrue som jeg argumenterte for.

Problemet med skafoidfrakturer har vært at man kun har vært opptatt av å få bruddet til å tilhele. Man har lagt på gips uten å gjøre forsøk på å reponere en fraktur med noe dislokasjon. Dette fører til at et betydelig antall brudd tilheler med feilstilling (humpback deformity). Dette gir ofte langvarige eller permanente smerter fra håndleddet. Jeg har selv etterundersøkt en del gipsede pasienter, og om lag halvparten hadde smerter to år etter bruddet. Ved perkutan osteosyntese kan man lett reponere frakturen med ledepinnen.

De siste årene er det publisert en rekke studier med perkutan operasjonsteknikk med en tilhelingsrate på $100 \%$. Disse studiene er også referert til i undersøkelsen til McQueen og medarbeidere, som viste at skruefikserte pasienter hadde en gjennomsnittlig sykmeldingstid på 27 dager mot 80 dager i den gipsede gruppen (2).

Andre studier viser åtte dager sykmelding og 43 dager til tilheling i skruegruppen mot 55 dager sykmelding og 74 dager til tilheling i konservativ gruppe (3).

Røkkum \& Melhuus hevder at den operative metoden er vanskelig. Da tror jeg neppe de kan ha prøvd den nye perkutane teknikken med kanylerte skruer som er utrolig enkel. I våre naboland bruker en assistentlege i gjennomsnitt ca. 20 minutter på en slik operasjon.

Man skal heller ikke se bort fra den ulempen det er for mange pasienter å gå med gips i månedsvis. Vi opplever derfor i økende grad at pasientene ber om å bli operert fremfor å få konservativ behandling.

På det forrige kurset $\mathrm{i}$ håndkirurgi for spesialistkandidater stilte jeg følgende spørsmål til auditoriet «Hvis dere selv får en skafoidfraktur, vil dere da gipses eller ha en perkutan operasjon med kanylert skrue?» De ti foreleserne og $90 \%$ av kursdeltakerne ønsket operativ behandling. Da bør vi også kunne tilby denne formen for behandling til våre pasienter.
Litteratur

1. Vinnars B, Pietreanu M, Bodestedt $\AA$ et al. Nonoperative compared with operative treatment of acute scaphoid fractures. A randomized clinical trial. J Bone Joint Surg Am 2008: 90 : 11

2. McQueen MM, Gelbke MK, Wakefield A et al. Percutaneous screw fixation versus conservative treatment for fractures of the waist of the scaphoid. J Bone Joint Surg Br 2008; 90: 66-71.

3. Arora R, Gschwentner M, Krappinger D. Fixation of nondisplaced scaphoid fractures: making treatment cost effective. Prospective controlled trial. Arch Orthop Trauma Surg 2007; 127: 39-46.

\section{Regelrytteri i blăreseptordningen}

I Tidsskriftet nr. 8/2009 viser Gro Hillestad Thune at rigide regler kan virke mot sin hensikt, og skade den som skulle beskyttes av dem (1). Hun oppfordrer leger til å praktisere på grunnlag av egne medisinskfaglige vurderinger, medmenneskelighet og sunn fornuft.

Jeg ønsker å utvide Thunes bekymringer til å gjelde myndighetenes krav om valg av legemidler på blåresept. Staten har satt opp svært detaljerte lister over medikamenter legene skal bruke til gitte tilstander. Disse listene er satt opp på grunnlag av pris og ikke på grunnlag av beste medisinske behandling. Jeg har mange ganger kommet $i$ en etisk og medisinsk problemstilling: Dersom jeg følger regelverket, vil min pasient få en mindreverdig behandling, en behandling jeg selv aldri ville hatt, en behandling jeg ikke ville gitt min kone eller mine barn. Men min ubemidlede minstepensjonist må ta til takke med et slikt preparat uten at han eller hun har mulighet til å betale ekstra for å få et preparat som er i samsvar med beste medisinske praksis. Grunnet økende detaljstyring fra myndighetene, vil legen oftere og oftere komme i konflikt mellom å være tro mot regelverket og å være tro mot det å utøve legeyrket i samsvar med beste medisinske praksis. Vi må aldri komme til det punkt at legene gir etter for myndighetskrav når slike krav strider mot det som er pasientens beste. Jeg vil oppfordre alle praktiserende leger til å lese innlegget til Gro Hillestad Thune en gang til. Juristeriet må stanses i starten!

\section{Ole Terland}

Indre Arna

\section{Litteratur \\ 1. Thune GH. Vis klør mot juristeriet. Tidsskr Nor Legeforen 2009; 129: 769}

